\title{
Uji Teknis dan Ekonomis Komponen Pengendalian Hama Penyakit Terpadu pada Usaha Tani Tomat
}

\author{
(Technical and Economic Tests for Components of Integrated Pests - Diseases Management on Tomato Farming)
}

\author{
Evy Latifah $^{1}{ }^{*}$, Hanik A. Dewi ${ }^{1}$, Putu B. Daroini ${ }^{1}$, Abu Z. Zakaria ${ }^{1}$, Joko Mariyono ${ }^{2}$, dan Arief L. Hakim ${ }^{3}$ \\ 1) Balai Pengkajian Teknologi Pertanian Jawa Timur, Malang \\ 2) Program Studi Magister Manajemen, Universitas Pancasakti, Tegal \\ 3) Universitas Islam Raden Rahmat, Malang \\ *Email korespondensi: evy_latifah@yahoo.com
}

Diterima 23 Januari 2018/Disetujui 15 Maret 2018

\begin{abstract}
Tomato is an important horticultural commodity, but the production is still low. One of the causes is the attack of pests and diseases. Integrated pest-disease management (IPDM) packages in order to increase tomato production need to be assessed. This study was conducted in November 2013-February 2014 with two integrated pest-disease control packages namely the Plant Growth-Promoting Rhizobacteria (PGPR) utilization package; package of utilization of local microorganisms. As a comparison, local farmers' practices were selected. The results show that plant growth and production of tomato using PGPR was the highest. The rate of attack of some pests and diseases in both IPDM is relatively lower than the farmers' practicess. Economic analysis also shows that the benefits gained with IPDM were higher than those of farmers' practices.
\end{abstract}

Keywords: biological agents, integrated pest-disease control, technology adoption, tomato farming.

\section{ABSTRAK}

Tomat merupakan komoditas hortikultura yang penting, tetapi produksinya masih rendah. Salah satu penyebab adalah serangan hama dan penyakit. Paket pengendalian hama-penyakit terpadu (PHPT) dalam rangka meningkatkan produksi tomat perlu dikaji. Kajian ini dilaksanakan pada bulan November 2013 - Februari 2014 dengan dua paket pengendalian hama-penyakit terpadu yaitu paket pemanfaatan Plant Growth-Promoting Rhizobacteria (PGPR); paket pemanfaatan mikroorganisme lokal. Sebagai pembanding dipilih kebiasaan petani setempat. Hasil pengkajian menunjukkan bahwa pertumbuhan tanaman dan produksi tomat yang menggunakan PGPR paling tinggi. Tingkat serangan beberapa hama dan penyakit pada kedua PHPT relatif lebih rendah dari pada kebiasaan petani. Analisis usahatani juga menunjukkan bahwa keuntungan yang diperoleh dengan PHPT lebih tinggi daripada keutungan dengan kebiasaan petani.

Kata kunci: adopsi teknologi, agensia hayati, pengendalian hama-penyakit terpadu, usahatani tomat.

\section{PENDAHULUAN}

Tomat merupakan komoditas hortikultura sayuran yang potensial. Hal ini untuk memenuhui kebutuhan secara nasional, baik untuk industri pengolahan makanan, konsumsi rumah tangga, maupun campuran bahan olahan (Mariyono et $a l ., 2017)$. Jika dibudidayakan secara intensif, usahatani tomat dapat memberikan keuntungan yang potensial (Mariyono, 2017b). Permintaan tomat, bersama dengan produk hortikultura sayuran lainnya, secara nasional terus meningkat, seiring dengan laju pertumbuhan penduduk dan kesadaran komsumsi yang sehat (Latifah, Andri and Mariyono, 2014). Produktivitas tomat perlu peningkatan untuk memenuhi permintaan tersebut, baik dari segi kuantitas dan kualitas. Banyak faktor yang menyebabkan rendahnya produksi dan kualitas tomat, antara lain adalah struktur tanah yang tidak mendukung, miskin unsur hara mikro, pemupukan tidak berimbang, serangan hama dan penyakit, pengaruh cuaca dan iklim, dan teknis budidaya petani yang diadopsi petani (Mariyono, 2017a).

Gambar 1 menunjukkan dinamika produksi tomat pada tingkat nasional. Dalam kurun waktu sepuluh tahun, hanya terjadi sedikit peningkatan. Bahkan, dapat dikatakan bahwa produksi nasional stagnan pada level di bawah satu juta ton. Oleh karena itu, kebutuhan tomat untuk industri makanan selama ini dipenuhui oleh tomat impor dalam bentuk pasta. 


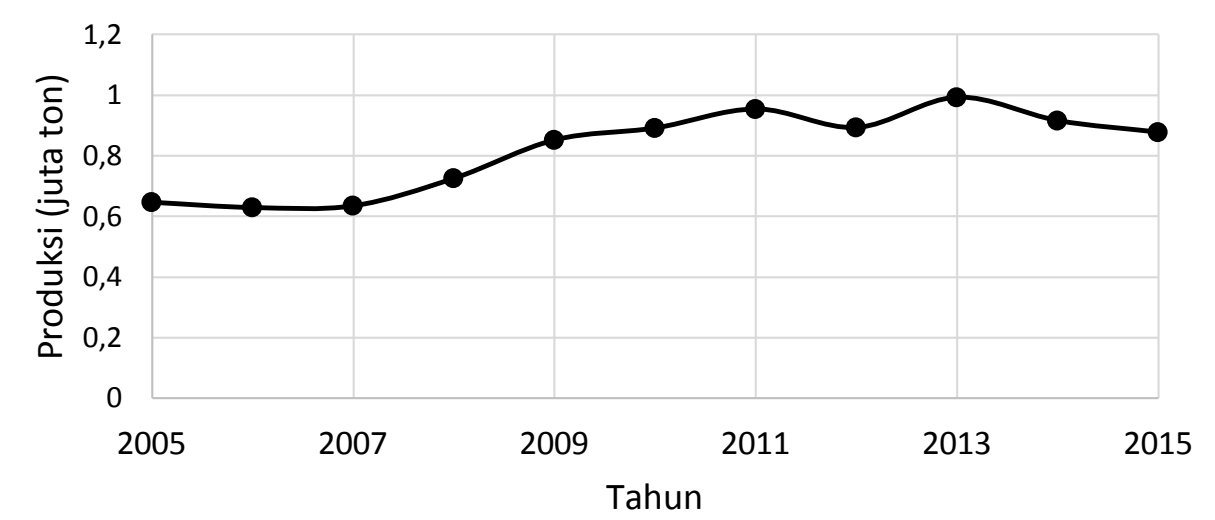

Sumber: BPS, 2016

Gambar 1. Tren produksi tomat nasional

Sedangkan produksi tomat segar hanya untuk konsumsi seharihari. Upaya peningkatan produksi tomat ke depan masih dan akan terus bertumpu pada penggunaan input luar, diantaranya perbaikan kesuburan tanah dengan penggunaan pupuk hayati, pestisida nabati untuk mengurangi penggunaan bahan-bahan yang mengandung bahan kimia. Pupuk hayati dan pestisida nabati yang digunakan juga untuk mengurangi pengeluaran untuk membeli pestisida dan pupuk anorganik sekaligus mengatasi dampak negatif yang ditimbulkannya.

Pengendalian hama-penyakit terpadu (PHPT) memiliki arti penting dalam mendukung adanya pertanian berkelanjutan. Hal ini dikarenakan konsep dalam PHPT selaras dengan konsep dalam pertanian berkelanjutan (Mariyono \& Setyoko, 2006). Disamping itu, PHPT dan pertanian berkelanjutan merupakan suatu kebijakan pemerintah yang diatur UndangUndang (Kuntariningsih \& Mariyono, 2013). Menurut Smith (1978), bahwa PHPT adalah pendekatan ekologi yang bersifat multidisiplin untuk pengelolaan populasi hama dengan memanfaatkan beraneka ragam teknik pengendalian secara compatible dalam satu kesatuan koordinasi pengelolaan. Kenmore (1987), menyatakan melalui penerapan PHPT diharapkan kerusakan yang ditimbulkan hama tidak merugikan secara ekonomi, sekaligus menghindari kerugian bagi manusia, binatang, tanaman dan lingkungan.

PHPT disebut pengendalian secara multilateral karena menggunakan semua metode yang dikenal. PHPT tidak bergantung pada satu cara, melainkan gabungan semua teknik pengendalian yang dikombinasikan secara terpadu dalam satu kesatuan pengelolaan (Mariyono, 2008). Sehingga tidak fokus pada penanaman varietas tahan saja atau hanya menghindari penggunaan pestisida yang berlebihan tetapi semua teknik dikombinasikan secara terpadu. PHPT juga harus dapat dipertanggungjawabkan secara ekologi dan penerapannya tidak menimbulkan kerusakan lingkungan yang merugikan bagi mahluk baik sekarang maupun yang akan datang. Teknik pengendalian hama dan penyakit tanaman diantaranya: (1) teknik agronomi misalnya dengan pengolahan tanah, irigasi, pemberoan, pergiliran tanaman, pengaturan jarak tanam, tanam serempak, dan pemupukan berimbang; (2) teknik varietas tahan misalnya dengan ketahanan genetik dan ketahanan ekologi; (3) teknik fisik dan mekanik misalnya dengan menggunakan lampu perangkap, menggunakan metilat lem, gelombang suara, pemasangan perangkap; (4) teknik pengendalian hayati misalnya menggunakan musuh alami dengan bahan bahan ramah lingkungan baik yang berasal dari makhluk hidup maupun dari tanaman; dan (5) teknik pengendalian kimiawi yaitu dengan menggunakan pestisida kimia yang tetap digunakan jika semua teknik sebelumnya tidak mampu dan merugikan (Peshin \& Zhang, 2014).

Pengendalian secara biologi dilakukan dengan pelestarian dan pemanfaatan agens pengendalian hayati (agen biokontrol) diantaranya dengan memanfaatkan musuh alami seperti predator (laba-laba), parasitoid (Trichogramma sp.), cendawan entomopatogen (Beauveria bassiana, Metarhizium anisopliae), bakteri entomopatogen (Bacillus thuringiensis) dan nematoda entomopatogen (family Steinernematidae dan Heterorhabditidae). Terdapat beberapa kendala implementasi PHPT di lapang yaitu: Rendahnya pola pikir petani tentang arti penting PHPT, keterbatasan sumber dana sehingga penelitian dilakukan sepotong-sepotong dan tidak berkesinambungan dan belum ada koordinasi dan kerangka dasar yang menyatukan kegiatan-kegiatan penelitian guna penerapan dan pengembangan PHT, baik antarlembaga penelitian maupun antar peneliti (Peshin and Zhang, 2014; Mariyono et al., 2013).

PHPT adalah suatu cara pendekatan atau cara berpikir tentang pengendalian organisme pengganggu tanaman (OPT) yang didasarkan pada pertimbangan ekologi dan efisiensi ekonomi dalam rangka pengelolaan agroekosistem yang berwawasan lingkungan (Ilham, 2014). Pengendalian OPT hortikultura yang diarahkan pada pengendalian yang memperhatikan aspek teknis, ekologis, sosial dan ekonomi (Mariyono, 2016). 
Pengendalian OPT yang ramah lingkungan tersebut diantaranya dengan menggunakan aplikasi agens hayati dan pestisida nabati (bahan alam/ berbahan dasar metabolit sekunder dari tanaman). Agens hayati yang telah banyak digunakan untuk mengendalikan OPT diantaranya: PGPR, Trichoderma sp, dan bakteri Serratia (Susetyo, 2012). Extrak daun tanaman tertentu juga mempunyai khasiat untuk mengendalikan hama(Harinta, 2013); Herminanto, Nurtiati, \& Kristianti, 2010). Agensia hayati, khususnya PGPR (Paramanandham, Rajkumari, Pattnaik, \& Busi, 2017), demikian juga Trichiderma (Paramanandham et al., 2017) dapat memberi manfaat untuk kesehatan dan ketahanan tanaman sayuran termasuk tomat. PGPR sangat diperlukan tanaman karena memiliki banyak manfaat diantaranya dapat meningkatkan produksi tanaman (Gupta, Kaushal, \& Sood, 2017), dan memproduksi antibiotik untuk melindungi tanaman dengan cara menghambat penyakit perakaran, dapat menjadi pesaing untuk memperoleh makanan bagi pathogen penyebab penyakit, merangsang pembentukan hormon atau ZPT, menghambat produksi etylen, meningkatkan penyerapan dan pemanfaatan unsur N, Fe, S, P dan Mn (Anonymous, 2013).

Salah satu agensia hayati yang dapat dimanfaatkan sebagai bahan pengendali OPT yang bersifat ramah lingkungan adalah bakteri Serratia atau bakteri merah merupakan bakteri gram negative yang memiliki flagella pertrik sehingga bersifat motil (Priyatno et al., 2011). Mekanisme kerja dari bakteri merah seperti pathogen serangga lainnya, yaitu mematikan secara oral dimana bakteri tersebut masuk atau tertelan ke dalam tubuh serangga hama dan masuk dalam pencernaan sehingga dapat merusak system pencernaan makanan serangga tersebut (Retnowati \& Wibowo, 2008). Disamping itu terdapat mikroorganisme lokal (MOL) yang bahan-bahan untuk pembuatannya tersedia di sekitar kita, bias berasal dari sampah dapur, bonggol pisang, air kelapa, air sisa cucian beras, nasi busuk, buah-buahan busuk, urine sapi, bonggol pisang dan batang pisang (Anonymous, 2013). Penggunaan teknologi yang tepat guna, murah dan ramah lingkungan perlu dikembangkan dan diverifikasi sebelum diintroduksi ke petani. Adopsi teknologi diharapkan dapat meningkatkan kesejahteraan petani dan memajukan pembangunan pedesaan yang berkelanjutan (Kuntariningsih \& Mariyono, 2014). Pengkajian ini bertujuan untuk menganalisis dua komponen PHPT secara agronomi dan ekonomi paket pengendalian hama dan penyakit terpadu pada usahatani tomat di Kediri.

\section{METODE PENELITIAN}

Pengkajian dilakukan di desa Kebonrejo kecamatan Kepung, desa Kamping Baru kecamatan Kepung, dan didesa Padangan kecamatan Kayen Kidul pada bulan November 2013 sampai dengan Februari 2014 yang berada pada ketinggian tempat $400 \mathrm{~m}$ diatas permukaan laut. Varietas tomat yang digunakan adalah Timoty. Kajian ini dilaksanakan pada lahan petani dengan luas $\pm 500 \mathrm{~m}^{2}$. Petani yang dilibatkan sebanyak 3 orang dan juga berfungsi sebagai ulangan. Adapun susunan perlakuan disajikan pada Table 1

Terdapat tiga paket perlakuan, yaitu: dua paket perlakuan menerapkan prinsip PHPT, A=paket pemanfaatan PGPR dan bakteri merah, $\mathrm{B}=$ paket pemanfaatan $\mathrm{MOL}$ dan satu paket sebagai control yang menggunakan kebiasaan petani (non PHT). Untuk mengendalikan hama diberikan, pestisida nabati yang terbuat dari jagung, tembakau, sereh, daun mindi, gadung, dan daun tapak liman. Jumlah masingmasing bahan satu $\mathrm{kg}$. Untuk mengendalikan penyakit, dibuat fungisida nabati yang terbuat dari bawang putih, jahe, kunyit dan daun tapak liman, yang masing masing-masing seberat satu kg. Semua bahan dihaluskan menjadi satu kemudian direndam selama satu malam. Campuran tersebut berupa pasta kental. Pada saat aplikasi, lima sendok makan pasta dilarutkan ke dalam tangki ditambah 10 liter air dan setengah sendok teh sabun cair sebagai pengelmusi larutan.

Data yang dikumpulkan untuk mengetahui tingkat efektifitas pengendali hama penyakit terpadu adalah pertumbuhan tanaman, prosentase hama dan penyakit yang menyerang, produksi tanaman dan analisa usaha tani.

Analisa data dilakukan dengan uji berganda Duncan. Untuk mengetahui keuntungan petani dilakukan dengan analisis finansial atau analisis usaha tani dengan menghitung R/C usahatani (Sudana, Ilham, Sadra, \& Rita, 1999).

\section{HASIL DAN PEMBAHASAN}

\section{Pertumbuhan Tanaman}

Pemberian PGPR dan MOL menunjukan kecenderungan rata-rata pertumbuhan yang lebih tinggi dari pada kebiasaan petani (Tabel 2). Meskipun setelah dianalisis secara statistik data pertumbuhan tinggi tanaman pada ketiga perlakuan tidak berbeda nyata berdasarkan analisis uji berganda Duncan. Hal ini disebabkan PGPR juga dapat merangsang pembentukan hormon atau zat pengatur tumbuh seperti Auksin, Gibberellin dan Sitokinin sehingga tanaman terlihat subur, begitu pula dengan bonggol pisang juga mengandung zat pengatur tumbuh Giberellin dan Sitokinin (Maspary, 2012).

Hasil penelitian menunjukkan bahwa PGPR $P$. fluorescens. dapat meningkatkan tinggi tanaman dan bobot buah cabai rata-rata sampai dengan 2,17g per tanaman (Ayun, Hadiastono, \& Martosudiro, 2013). Ditunjukkan pula pada sebuah penelitian bahwa perkecambahan, kelangsungan hidup, tinggi tanaman dan berat kering secara significan meningkat dengan perlakuan PGPR dalam kondisi non-garam dan bergaram (Yachana \& Subramanian, 2013). Perlakuan MOL bonggol pisang menunjukkan pertumbuhan cukup tinggi dibanding perlakuan kebiasaan petani, hal ini disebabkan bahwa MOL bonggol pisang juga mengandung 7 mikroorganisme yang sangat berguna bagi tanaman yaitu: Azospirilium, Azotobacter, Bacillus, Aeromonas, Aspergillus, mikroba pelarut phospat dan mikroba selulotik, disamping itu 
Tabel 1. Perlakuan paket pengendalian hama-penyakit terpadu



Sumber: data primer

Tabel 2. Pertumbuhan tanaman tomat pada berbagai hari setelah tanam (hst)

\begin{tabular}{lccccccccccc}
\hline Perlakuan & $14 \mathrm{hst}$ & $21 \mathrm{hst}$ & $28 \mathrm{hst}$ & $35 \mathrm{hst}$ & $42 \mathrm{hst}$ & $49 \mathrm{hst}$ & $56 \mathrm{hst}$ & $63 \mathrm{hst}$ & $70 \mathrm{hst}$ & $77 \mathrm{hst}$ & $84 \mathrm{hst}$ \\
\hline PGPR & $29 \mathrm{a}$ & $38 \mathrm{a}$ & $51 \mathrm{a}$ & $63 \mathrm{a}$ & $81 \mathrm{a}$ & $97 \mathrm{a}$ & $118 \mathrm{a}$ & $134 \mathrm{a}$ & $139 \mathrm{a}$ & $145 \mathrm{a}$ & $151 \mathrm{a}$ \\
\hline MOL & $28 \mathrm{a}$ & $35 \mathrm{a}$ & $51 \mathrm{a}$ & $62 \mathrm{a}$ & $80 \mathrm{a}$ & $96 \mathrm{a}$ & $116 \mathrm{a}$ & $133 \mathrm{a}$ & $138 \mathrm{a}$ & $144 \mathrm{a}$ & $150 \mathrm{ab}$ \\
\hline Kontrol & $28 \mathrm{a}$ & $34 \mathrm{a}$ & $50 \mathrm{a}$ & $62 \mathrm{a}$ & $79 \mathrm{a}$ & $95 \mathrm{a}$ & $116 \mathrm{a}$ & $132 \mathrm{a}$ & $137 \mathrm{a}$ & $144 \mathrm{a}$ & $150 \mathrm{a}$ \\
\hline
\end{tabular}

Catatan: angka diikuti dengan huruf yang sama menunjukan tidak berbeda nyata

Sumber: Analisis data primer

juga dapat digunakan sebagai decomposer atau mempercepat proses pengomposan (Maspary, 2012).

\section{Serangan Hama dan Penyakit}

Pengendalian hama dan penyakit tomat menjadi faktor utama kunci keberhasilan budidaya tanaman tomat. Dengan demikian tanaman tomat yang mendapatkan aplikasi PGPR dan bakteri merah selama pertumbuhan cenderung lebih sedikit serangan hama dan penyakitnya, begitu pula dengan aplikasi bonggol pisang dan pestisida nabati untuk pengendalian hama penyakit cenderung lebih efektif dibandingkan kebiasaan petani dengan menyemprotkan pestisida kimia. Dengan demikian teknik pengendalian hama penyakit terpadu yang telah dilakukan lebih meminimalkan serangan hama dan penyakit sehingga lebih terkendali.

Serangan hama dan penyakit disajikan pada Tabel 3. Pengamatan dimulai pada umur 14 hst tanaman menunjukkan bahwa serangan kutu kebul rata-rata $2 \%$ per tanaman pada tanaman yang mendapat perlakuan PGPR dan bonggol pisang, untuk perlakuan kebiasaan petani lebih tinggi prosentasi serangan kutu kebul sebanyak $3 \%$ per tanaman. Kemudian pada umur 21 hst berkembang penyakitnya, terdapat bercak daun rata-rata $2 \%$ per tanaman dengan rata-rata populusi kutu kebulnya tetap 3\% per tanaman. Dengan keberadaan kutu kebul pada umur vegetatif tanaman dapat berpotensi sebagai vektor penular virus penyebab penyakit. Hama kutu kebul yang menyerang tanaman tomat adalah spesies Bemisia tabaci. Hama terlihat berwarna putih, memilikia sayap serta bagian tubuh berselimut lilin. Serangan Bemisia tabaci mengakibatkan kerusakan pada sel-sel atau jaringan daun tomat karena cairannya dihisap habis oleh hama.

Pada kedua perlakuan PHPT pada umur 35 hst mulai terserang bercak daun rata-rata sebanyak 2 dan $3 \%$ pada setiap setiap tanaman penyebabnya adalah: cendawan Septoria lycopersici Speg. yang merusak daun dan menyerang tanaman tomat yang masih muda ataupun tua (Paramanandham et al., 2017). Gejala: terlihat bercak bulat kecil berair pada kedua permukaan daun dibagian bawah. Bercak tersebut berwarna coklat muda, kemudian menjadi kelabu dengan tepi kehitaman. Garis tengah bercak $\pm 2 \mathrm{~mm}$. Serangan yang hebat menyebabkan daun tomat menggulung, mengering dan rontok. Dan dengan bertambahnya umur tanaman tomat, bercak daun yang menyerang semakin banyak terutama pada perlakuan 
Tabel 3. Tingkat serangan hama dan penyakit

\begin{tabular}{lllll}
\hline NO & Umur Tanaman & \multicolumn{2}{c}{ Hama } & \\
\cline { 3 - 5 } & & PGPR & MOL & Kontrol \\
\hline 1 & $14 \mathrm{hst}$ & Kutu kebul 2\% & Kutu kebul 2\% & Kutu kebul 3\% \\
2 & $21 \mathrm{hst}$ & - & & Bercak daun 2\% \\
3 & $28 \mathrm{hst}$ & Bercak daun 2\% & Bercak daun 3\% & Bercak daun 5\% \\
4 & $35 \mathrm{hst}$ & Bercak daun 5\% & Bercak daun 10\% & Bercak daun 20\% \\
5 & $42 \mathrm{hst}$ & Bercak daun 5\% & Bercak daun 12\% & Bercak daun 25\% \\
6 & $49 \mathrm{hst}$ & Bercak daun 15\% & Bercak daun 25\% & Bercak daun 50\% \\
7 & $56 \mathrm{hst}$ & Bercak daun 20\% & Bercak daun 30\% & Bercak daun 70\% \\
8 & $63 \mathrm{hst}$ & Bercak daun 50\% & Bercak daun 55\% & Bercak daun 70\% \\
9 & $70 \mathrm{hst}$ & Bercak daun 55\% & Bercak daun 60\% & Bercak daun 70\% \\
\hline
\end{tabular}

Sumber: Analisis data primer

Tabel 4. Hasil produksi tanaman tomat (kg/plot)

\begin{tabular}{lllll}
\hline Perlakuan & Lokasi I & Lokasi II & Lokasi III & Rata-rata \\
\hline PGPR & 23.5 & 24 & 24.5 & $24.00 \mathrm{a}$ \\
MOL & 22.8 & 23.5 & 23.18 & $22.20 \mathrm{c}$ \\
Kebiasaan Petani & 22.4 & 22.2 & 22.0 & $23.16 \mathrm{~b}$ \\
\hline
\end{tabular}

Catatan: angka diikuti dengan huruf yang sama menunjukan tidak berbeda nyata

Sumber: Analisis data primer

kebiasaan petani mulai umur 42 hst, 49 hst, 56 hst, 63 hst sudah terserang rata-rata sebanyak $20 \%$ pada setiap tanaman berkembang lagi menjadi $25 \%$ pada setiap tanaman kemudian $50 \%$ pada umur 56 hst, dan berkembang lagi bercak daunnya menjadi 70\% sampai dengan 84 hst. Perlakuan pemberian PGPR dan bakteri merah relative lebih sedikit persentase serangan kutu kebul dan bercak daun.

Hal ini sesuai dengan hasil penelitian Priyatno et al., (2011) yang membuktikan bahwa bakteri merah yang diisolasi dari wereng batang coklat memiliki kisaran inang yang luas dan tidak terbatas pada serangga hama, tetapi juga bakteri pathogen tanaman, sehingga pemanfaatannya selain untuk mengendalikan serangga hama juga bakteri pathogen tanaman.

Hasil penelitian Hersanti (2007) dan Hersanti, Istifadah, \& Djaya (2009), menunjukkan bahwa kemampuan antagonistik isolat-isolat bakteri hasil isolasi dari MOL bonggol pisang P. grisea memperoleh 14 isolat bakteri yang tidak berpotensi meningkatkan pertumbuhan benih padi tetapi mampu menekan perkembangan penyakit bercak daun coklat pada tanaman padi di rumah kaca. Hasil tinjauan di negara lain menunjukkan bahwa ada dampak penggunaan PGPR terhadap pertumbuhan tanaman (Gupta et al., 2017).

\section{Produksi Tanaman}

Perbandingan produksi tanaman disajikan pada Tabel 4. Pemberian PGPR mampu menghasilkan produksi yang paling tinggi. Hal ini karena PGPR mampu meningkatkan penyerapan dan pemanfaatan unsur $\mathrm{N}$ oleh tanaman, dapat meningkatkan kemampuan tanaman dalam menyerap unsur $\mathrm{Fe}, \mathrm{S}, \mathrm{P}$, dan $\mathrm{Mn}$, merangsang pembentukan hormon atau ZPT, mampu menjadi pesaing pathogen penyebab penyakit dalam mendapatkan makanan di sekitar perakaran serta dapat memproduksi antibiotic dengan cara menghambat pertumbuhan penyakit perakaran (Maspary, 2011). Ditambahkan pula bahwa penambahan PGPR dapat menyebabkan kondisi lingkungan dalam tanah stabil dan berkelanjutan serta dapat meningkatkan produksi dan kesehatan tanaman (Saharan \& Nehra, 2011) dan pertumbuhan tanaman (Gupta et al., 2017)

\section{Analisis Ekonomi Usahatani}

Analisis usahatani teknologi PHPT dihitung bedasarkan luas plot percobaan. Komponen biaya usahatani terdiri atas sewa lahan, persiapan lahan, tanam, pemeliharaan, dan tenaga kerja. Hasil analisis usaha tani disajikan pada Tabel 5. dengan pemberian PGPR menghasilkan keuntungan yang paling tinggi, kemudian pemberian MOL dan perlakuan kebiasaan petani menghasilkan keuntungan yang paling rendah.

Meskipun perlakuan pemberian MOL menghasilkan produksi yang paling rendah dibanding kedua perlakuan yang lain tetapi mampu menghasilkan $\mathrm{R} / \mathrm{C}$ yang paling tinggi, karena untuk aplikasi MOL tidak memerlukan pembelian pestisida kimia yang mahal, cukup memanfaatkan bahanbahan yang ada disekitar serta membuat sendiri bahan-bahan tersebut, sehingga biaya yang dikeluarkan lebih murah 
Tabel 5. Analisa Usahatani Tanaman Tomat (per $150 \mathrm{~m}^{2}$ )

\begin{tabular}{|c|c|c|c|c|c|c|}
\hline \multirow[b]{2}{*}{ Uraian Kegiatan } & \multicolumn{2}{|c|}{ IPM (PGPR) } & \multicolumn{2}{|c|}{ IPM (MOL) } & \multicolumn{2}{|c|}{ Kebiasaan Petani } \\
\hline & Luas & Jumlah (RP, -) & Luas & lah (RP, - & Luas & Jumlah (RP, - ) \\
\hline Sewa Tanah & $150 \mathrm{~m} 2$ & 160.000 & $150 \mathrm{~m} 2$ & 160.000 & $150 \mathrm{~m} 2$ & 160.000 \\
\hline $\begin{array}{l}\text { Pengolahan Tanah } \\
* \text { Bajak, garu } 1 \text { kali }\end{array}$ & & 100.000 & & 100.000 & & 100.000 \\
\hline * Membuat bedengan & & 100.000 & & 100.000 & & 100.000 \\
\hline $\begin{array}{l}\text { Pupuk organik / Petroganik } \\
\text { Mulsa Plastik }\end{array}$ & $175 \mathrm{~kg}$ & $\begin{array}{l}87.500 \\
66.000\end{array}$ & $175 \mathrm{~kg}$ & $\begin{array}{l}87.500 \\
66.000\end{array}$ & $175 \mathrm{~kg}$ & $\begin{array}{l}87.500 \\
66.000\end{array}$ \\
\hline $\begin{array}{l}\text { Bibit perbatang Rp. } 200 \\
\text { (Timoty) }\end{array}$ & $300 \mathrm{btg}$ & 60.000 & $300 \mathrm{btg}$ & 60.000 & $300 \mathrm{btg}$ & 60.000 \\
\hline $\begin{array}{l}\text { Tenaga tanam } \\
\text { Pupuk Phonska }\end{array}$ & & 30.000 & & 30.000 & & 30.000 \\
\hline MOL & & & & 20.000 & 6 kali & 112.000 \\
\hline Bambu dan tenaga & & 20.000 & & 20.000 & & 20.000 \\
\hline Pestisida: & & & & & & \\
\hline Demolish, Alika, Perekat & & 0 & & 0 & & 125.000 \\
\hline Nabati & & 70.000 & & 20.000 & & 0 \\
\hline Tenaga nyemprot dan kocor & & 100.000 & & 100.000 & & 50.000 \\
\hline Tenaga penyiangan & & 25.000 & & 25.000 & & 25.000 \\
\hline $\begin{array}{l}\text { Pengairan } \\
\text { Agensia hayati }\end{array}$ & & $\begin{array}{l}15.000 \\
70.000\end{array}$ & & $\begin{array}{r}15.000 \\
0\end{array}$ & & $\begin{array}{r}15.000 \\
0\end{array}$ \\
\hline Total Biaya & & 903.500 & & 803.500 & & 950.500 \\
\hline Produksi & 600 & 1.500 .000 & 555 & 1387.500 & 580 & 1.450 .000 \\
\hline Harga & 2500 & & 2500 & & 2500 & \\
\hline Keuntungan & & 596.500 & & 584.000 & & 449.500 \\
\hline R/C Ratio & & 1,66 & & 1,72 & & 1,53 \\
\hline
\end{tabular}

Sumber: Analisis data primer

Mengingat bahwa tanaman tomat dapat menghasilkan keuntungan (Mariyono, 2017b), maka peningkatan produksi melalui adopsi komponen PHPT diharapkan dapat lebih meningkatkan pendapatan petani. Jika dilakukan secara intensif dan lebih komersial, maka usahatani tomat dapat meningkatkan taraf hidup petani seperti yang sudah dilakukan pada tanaman cabai (Mariyono, 2017b). Disseminasi konsep PHPT melalui sekolah lapangan secara luas diharapkan dapat mempengaruhi komoditas lain (Mariyono \& Negoro, 2016). Selanjutnya, karena komoditas tomat sangat peka terhadap pasokan musiman, maka peran system informasi dan teknologi luar musim, yaitu pada musim hujan mempunyai peran penting untuk menjaga keuntungan usahatani tomat (Negoro \& Mariyono, 2014).

\section{KESIMPULAN DAN SARAN}

Tomat merupakan komoditas hortikultura sayuran yang potensial, baik untuk industri pengolahan makanan, konsumsi rumah tangga, maupun campuran bahan olahan. Permintaan tomat secara nasional terus meningkat, seiring dengan laju pertumbuhan penduduk dan kesadaran komsumsi yang sehat. Produktivitas tomat perlu peningkatan untuk memenuhi permintaan tersebut. Penggunaan teknologi yang tepat guna, murah dan ramah lingkungan perlu dikembangkan dan diverifikasi sebelum diintroduksi ke petani. Kajian ini telah menguji dua komponen teknologi pengendalian hama-penyakit secara terpadu, yang dilakukan oleh petani.

Hasilnya, baik secara teknis/agronomis dan enonomis adalah sebagai berikut: (1) secara teknis, tinggi tanaman tomat tidak berbeda nyata dari 3 perlakuan yaitu pemberian PGPR, 
pemberian MOL bonggol pisang dan perlakuan petani. Hhasil produksi yang tertinggi dihasilkan oleh tanaman yang memperoleh PGPR dan bakteri merah; setingkat dibawahnya produksi tanaman yang memperoleh perlakuan MOL bonggol pisang dan yang terendah perlakuan petani; (2) tingkat serangan hama penyakit pada ke dua penerapan system PHPT lebih rendah dari pada perlakuan petani. Dimana pemberian PGPR dan bakteri merah relative paling sedikit serangan kutu kebul dan bercak daun; (3) secara ekonomis, analisa usaha tani pemanfaatan PGPR dan bakteri merah serta kebiasaan petani menghasilkan produksi tomat lebih tinggi, tetapi $\mathrm{R} / \mathrm{C}$ ratio tertinggi dihasilkan pada perlakuan pemanfaatan MOL.

Dari hasil kajian tersebut, dapat direkomendasikan bahwa komponen teknologi PHPT sudah dapat diintroduksikan kepada petani setempat. Untuk daerah lain dengan agroklimatologi yang berbeda, masih diperlukan kajian multilokasi dan disesuaikan dengan bahan bahan setepat yang tersedia. Untuk dapat menyakinkan para petani, praktisi, uji laboratorium perlu dilakukan. Uji laboratorium dapat dilakukan dengan bekerja sama dengan universitas dan lembaga penelitian pertanian, yang hasilnya dapat dipertangung-jawabkan secara ilmiah dan akademis.

\section{KETERBATASAN}

Mengingat bahwa kajian ini bersifat praktis, maka kajian memiliki keterbatasan sehingga diperlukan penelitian lanjutan yang secara teknis dapat menyempurnakan teknologi pengendalian hama-penyakit secara terpadu. Keterbatasan tersebut ada karena kajian ini dilakukan di lahan petani dan dikelola oleh petani. Hal-hal yang berhubungan dengan teknis pengukuran tidak terlalu akurat. Hal ini berkenaan dengan pestisida nabati, baik pada saat pembuatan maupun saat aplikasi, serta pada saat pengukuran hasil panen.

\section{UCAPAN TERIMA KASIH}

Penelitian ini merupakan bagian dari proyek "Vegetable for Indonesia", yang didanai oleh United States Agency for International Development (USAID) -Indonesia, bekerja sama dengan Balai Penelitian Tanaman Sayuran Indonesia, Balai Pengkajian Teknologi Pertanian Jawa Timur dan Bali, Dinas Pertanian Jawa Timur dan Bali, Universitas Udayana, dan FIELD Foundation Indonesia. Penulis mengucapkan terima kasih kepada para petani dan petugas lapangan yang menyediakan dan mencatat informasi yang berkaitan dengan percobaan lapangan. Setiap kesalahan dalam analisis dan interpretasi hasil analisis merupakan tanggung jawab semua penulis.

\section{DAFTAR PUSTAKA}

Anonymous. 2013. Cara pembuatan PGPR (plant growth promoting Rhizobacteria). Retrieved October 1, 2014, from http://luki2blog.wordpress.com/2013/12/27/cara- pembuatan-pgpr-plant-growth-promoting-rhizobacteria/ pada

Ayun, K.Q., T. Hadiastono, M. Martosudiro. 2013. Pengaruh penggunaan PGPR terhadap intensitas TMV, pertumbuhan dan produksi pada tanaman cabai rawit (Capsicum Frustescens L.). Jurnal Hama Penyakit Tanaman, 1(1): 47-56.

Gupta, S., R. Kaushal, G. Sood. 2017. Impact of plant growthpromoting Rhizobacteria on vegetable crop production. International Journal of Vegetable Science, hal. 1-12.

Harinta, Y.W. 2013. Efektifitas Tepung Daun Sirsak (Annona muricata) Untuk Mengendalikan Kumbang Bubuk Kedelai (Callosobruchus analis F.) Pada Biji Kedelai (Glycine max L.). Agrovigor. 6(2): 121-127.

Herminanto, Nurtiati, D.M. Kristianti. 2010. Potensi Daun Serai Untuk Mengendalikan Hama Callosobruchus Analis F. Pada Kedelai Dalam Simpanan. Agrovigor. 3(1):19-27.

Hersanti. 2007. Isolasi Bakteri Asal Larutan Mikroorganisme Lokal, Uji Antagonis, Uji Pertumbuhan Semai Padi. Universitas Padjadjaran.

Hersanti, N.I., L. Djaya. 2009. Potensi bakteri asal mikroorganisme lokal (MOL) dalam menekan penyakit dan meningkatkan pertumbuhan tanaman padi. Retrieved March 28, 2014, diunduh pada: http://www.lppm.unpad.ac.id/archives/3742

Ilham, S. 2014. Teknik Pengendalian Hama Terpadu. Retrieved March 28, 2014, from http://worldmeco.worldpress.com/2014/01/31/teknikpengendalian -hama-terpadu/

Kenmore, P.E. 1987. IPM means the best mix. Rice IPM Newsletter.

Kuntariningsih, A., J. Mariyono. 2013. Dampak pelatihan petani terhadap kinerja usahatani kedelai di Jawa Timur. Sosiohumaniora, 15(2):139-150. doi: https://doi.org/10.24198/sosiohumaniora.v15i2.5739

Kuntariningsih, A., J. Mariyono. 2014. Adopsi teknologi pertanian untuk pembangunan pedesaan: Sebuah kajian sosiologis. Agriekonomika. 3(2), 180-191.

Latifah, E., K.B. Andri, J. Mariyono. 2014. Pengenalan model kebun sayur sekolah untuk peningkatan konsumsi sayuran bagi para siswa di Kediri-Jawa Timur. Agriekonomika. 3(1):34-44. 
Mariyono, J. 2008. The impact of integrated pest management technology on insecticide use in soybean farming in Java, Indonesia: two models of demand for insecticides. Asian Journal of Agriculture and Development, $5(1): 43-56$.

Mariyono, J. 2016. Integrated disease management for chili farming in Brebes and Magelang-Central Java: Social economic impacts. Agriekonomika, 5(2):114-124. doi:https://doi.org/10.21107/agriekonomika.v5i2.1686

Mariyono, J. 2017a. Agro-ecological and socio-economic aspects of crop protection in chili-based agribusiness in Central Java. Agriekonomika. 6(2):120-132.

Mariyono, J. 2017b. Moving to commercial production: A case of intensive chili farming in Indonesia. Development in Practice. 27(8):103-1113. doi:https://doi.org/10.1080/09614524.2017.1360841

Mariyono, J. 2017c. Profitability and determinants of smallholder commercial vegetable production. International Journal of Vegetable Science (forthcoming.).doi:https://doi.org/10.1080/19315260.20 17.1413698

Mariyono, J., A. Kuntariningsih, H.A. Dewi, E. Latifah, P.B. Daroini, A.A. Negoro, G. Luther. 2017. Pathway analysis of vegetable farming commercialization. Economic Journal of Emerging Markets. 9(2):115-124. https://doi.org/10.20885/ejem.vol9.iss2.art1

Mariyono, J., G.C. Luther, M. Bhattarai, M. Ferizal, R. Jaya, N. Fitriana. 2013. Farmer field schools on chili peppers in Aceh, Indonesia: activities and impacts. Agroecology and Sustainable Food Systems. 37(9):1063-1077. doi:https://doi.org/10.1080/21683565.2013.819827

Mariyono, J., A.A. Negoro. 2016. Impact of farmers' knowledge on joint productions of rice and soybean in Central Java, Indonesia. Journal Animal Science and Agronomy Panca Budi. 1(1):7-16.

Mariyono, J., H. Setyoko. 2006. Determinants of adopting environmentally friendly technology: a case of soybean farming in East Java. Jurnal Pembangunan Pedesaan. $6(1): 15-24$.

Maspary. 2011. PGPR mengendalikan layu dan menyuburkan tanaman. Retrieved 6 Agustus 2014, from http://www.gerbangpertanian.com/2011/06/pgprmengendalikan-layu-dan-menyuburkan.html

Maspary. 2012. Kehebatan MOL bonggol pisang. Diakses pada tanggal 6 September 2014, from http://www.gerbangpertanian.com/2012/05/apakehebatan-mol-bonggol-pisang.html

Negoro, A.A., J. Mariyono. 2014. Peran sistem informasi dan teknologi luar musim dalam bisnis berbasis komoditas sayuran. In Prosiding Seminar Nasional PERHORTI 2014. Malang: PERHORTI.

Paramanandham, P., J. Rajkumari, S. Pattnaik, S. Busi. 2017. Biocontrol potential against Fusarium oxysporum f. sp. lycopersici and Alternaria solani and tomato plant growth due to Plant Growth-Promoting Rhizobacteria. International Journal of Vegetable Science. 23(4), 294 303.

Peshin, R., W. Zhang. 2014. Integrated pest management and pesticide use. In Integrated Pest Management. 3:1-46. doi:https://doi.org/10.1007/978-94-007-7796-5_1

Priyatno, T.P., Y.A. Dahliani, Y. Suryadi, I.M. Samudra, D.N. Susilowati, I. Rusmana, C. Irwan. 2011. Identifikasi entomopatogen bakteri merah pada wereng batang coklat (Nilaparvata lugens Stål.). Jurnal AgroBiogen. $7(2): 85-95$.

Retnowati, L., S.W. Wibowo. 2008. Perbanyakan dan Pemanfaatan Bakteri Merah. Jakarta: BBPOPT Jatisari, Direktorat Perlindungan Tanaman Pangan.

Saharan, B.S., V. Nehra. 2011. Plant growth promoting rhizobacteria: A critical review. Life Sciences and Medicine Research (Vol. LSMR).

Smith, R.F. 1978. History and complexity of integrated pest management. In Smith, E.H., D. Pimentel (Eds.), Pest control strategies. 41-53. New York: Academic Press.

Sudana, W., N. Ilham, D.K. Sadra, S.R. Rita. 1999. Metodologi Penelitian dan Pengkajian Sosial Ekonomi Pertanian. Jakarta: Badan Litbang Pertanian.

Susetyo, H.P. 2012. Potensi bakteri merah (Serratia sp.) sebagai entomopatogen pada komoditas hortikultura. Diakses pada tanggal 19 December 2014, from http://hendrypuguhsusetyo.wordpress.com/2012/07/03/ potensi-bakteri-merah-serratia-sp-sebagaientomopatogen-pada-komoditas-hortikultura

Yachana, J., R.B. Subramanian. 2013. Paddy plants inoculated with PGPR show better growth physiology and nutrient content under saline conditions. Chilean Journal of Agricultural Research. 73(3):213-219. 